\title{
Older adults are right: young people are more desensitized to violence
}

\begin{abstract}
Introduction

According to the Citizen Council for Public Safety and Criminal Justice (2017) Mexico has the most violent city in the world and an additional of cities rank amongst the most violent ones. Desensitization to violence is a process that occurs as a result of the exposure to violence either in the media or in real life. It produces the belief that violence is a trivial and inevitable process, even capable of generating positive emotions.
\end{abstract}

Method: Analytic cross sectional study was conducted. The study was conducted using a sample of 402 respondents (mainly volunteers) from San Luis Potosí and Tijuana; total mean of age was 29.4 SD 12.04. Of them 34 (8.5\%) admitted a crime an $368(91.5 \%)$ had never committed one. Instruments: Desensitization to Violence Scale for Adults from. ${ }^{1}$

Results: the correlation between age and desensitization to violence is $-.362 \mathrm{p}<.001$ young adults present greater desensitization to violence and a medium to high effect size in contrast to groups of mature and older adults.

Conclusion: the study of the desensitization to violence show that violence is changing perception and social labeling. The relation between age and desensitization is one of the evidences that proves necessary to address the consequences of exposure to violence.
Volume 3 Issue 3 - 2018

\section{Jaime Sebastián F Galán Jiménez, Omar Sánchez-Armáss Cappello}

Faculty of Psychology, Autonomous University of San Luis Potosí, Mexico

Correspondence: Jaime Sebastián F Galán Jiménez, Faculty of Psychology, Autonomous University of San Luis Potosí, Mexico, Tel +524448321000, Email Psic.sebastiangalan@gmail.com

Received: April 29, 2018 | Published: May 092018

\section{Introduction}

According to the Citizen Council for Public Safety and Criminal Justice $^{2}$ Mexico has the most violent city in the world and four places down appears Tijuana (place were part of the sample of this article was collected). According with the National Institute of Statistics Geography and Informatics ${ }^{3}$ the crimes reported in 2015 are significant less comparing to the year of 2016 and 37,037 out of 100,000 reported being crime victims, during the same year. Mexico occupied the 142th place out of 163 countries in the Global Peace Index. ${ }^{4}$

Social learning theory assures that the environment modifies perceptions and beliefs as well as it can model behavior. The way in which a person interprets or experiences an action (e.g. violence) is mediated by a phenomenon called "social labeling", hence, the acceptance of violence could be labeled as normative..$^{5-9}$

Violence implies the intention of harm, whether physical or psychological, it is relevant to a context, and is intimately related to the values among the society where it presents. ${ }^{10-12}$ Cooley-Strickland et al. ${ }^{13}$ assure that the indirect victims of violence are much more numerous (this refers to all the people surrounded by acts of violence, which in Mexico could lead to the conclusion that almost any person who lives in this country is exposed).

\section{Desensitization to violence}

\section{Desensitization to violence is defined by Galan \& Preciado (2014)}

Desensitization to violence is a process that occurs as a result of the exposure to violence either in the media or in real life. Furthermore, the phenomenon can be identified in the reduction of physiological, emotional, cognitive or psychological responses, as well as the perception or attention given to violent acts that were experienced or witnessed. In conclusion, desensitization to violence seems to produce the belief that violence is trivial and inevitable, even capable of generating positive emotions.

Alimardani et al. ${ }^{14}$ found association of desensitization and exposure to violence in media and neighborhoods. Diaz, Rivera \& Reyes affirmed that the people who lived in Ciudad Juarez became accustomed to violence. Mrug et al. ${ }^{15}$ concluded that violence in real life and its severity is more closely related to the desensitization to violence than violence coming from the media. Tarabah et al. ${ }^{16}$ found that attitudes and desensitization to violence in children exposed to violence were related to the frequency and normalization, they also noticed that desensitization is related to the imitation of aggression. Gaylord-Harden et al. ${ }^{17}$ associated desensitization with depressive and anxiety symptoms. Read et al. ${ }^{18}$ related arousal and desensitization to violence. Funk ${ }^{19}$ approached physical and psychological measures but to the best of our knowledge the investigations are related to youth.

\section{Method}

Analytic cross sectional study was conducted. Our study was confirmed by 402 volunteers from San Luis Potosí (75\%) and Tijuana $(25 \%)$, divided in 214 women $(53,2 \%)$ and 188 men $(46.8 \%)$. The sample is composed 320 young adults (79.6\%), 72 mature adults $(17.9 \%)$ and 10 senior adults $(2.5 \%)$ divided correspondently as follows 18 to 39 years old, 40 to 59 and 60 or more, the total mean of age was 29.4 SD 12.04. Participants were asked if they had ever been arrested for a crime, $34(8.5 \%)$ admitted a crime an $368(91.5 \%)$ had never committed one.

\section{Instruments}

Desensitization to Violence Scale for Adults from F Galán et 
al. ${ }^{20}$ the scale has a CFI .982, GFI.979, AVE of .85 and a Compose Reliability of .93 with six items unifactorial scale.

\section{Procedure}

The procedure proposed in this research was developed following the Ethical Principles of Psychologists and Code of Conduct, ${ }^{21}$ following section 8.05 about harmless research and anonymity, and section 8.8 regarding debriefing, voluntary participation and the possibility of sustaining communication with the investigators. The sample was collected from completely voluntary participants in both cities San Luis Potosí (SLP) and Tijuana. We use de free software JASP (2017) version 8.5.1. to do most of the statistical procedures. First, we obtained the correlation between age and desensitization to violence, afterwards the comparison between the different age groups and different cities, and finally we compared the groups of participants who committed a crime and those who did not.

\section{Results}

Described below are the results obtained from the previously described sample. The correlation between age and desensitization to violence can be appreciated in Table 1 and subsequently the comparison between the age groups in (Table 2) (Figure 1) contains the graphic with the means.

Table I Pearson correlations between desensitization to violence an age

\begin{tabular}{|c|c|c|c|}
\hline & & Age & \\
\hline \multirow{4}{*}{$\begin{array}{l}\text { Desensitization to } \\
\text { violence }\end{array}$} & Pearson's $r$ & \#VALUE! & $* * *$ \\
\hline & $\mathrm{p}$-value & $<.001$ & \\
\hline & Upper $95 \% \mathrm{Cl}$ & -0.274 & \\
\hline & Lower $95 \% \mathrm{Cl}$ & -0.444 & \\
\hline
\end{tabular}

$*_{\mathrm{p}}<.05, * *_{\mathrm{p}}<.01, * * *_{\mathrm{p}}<.001$

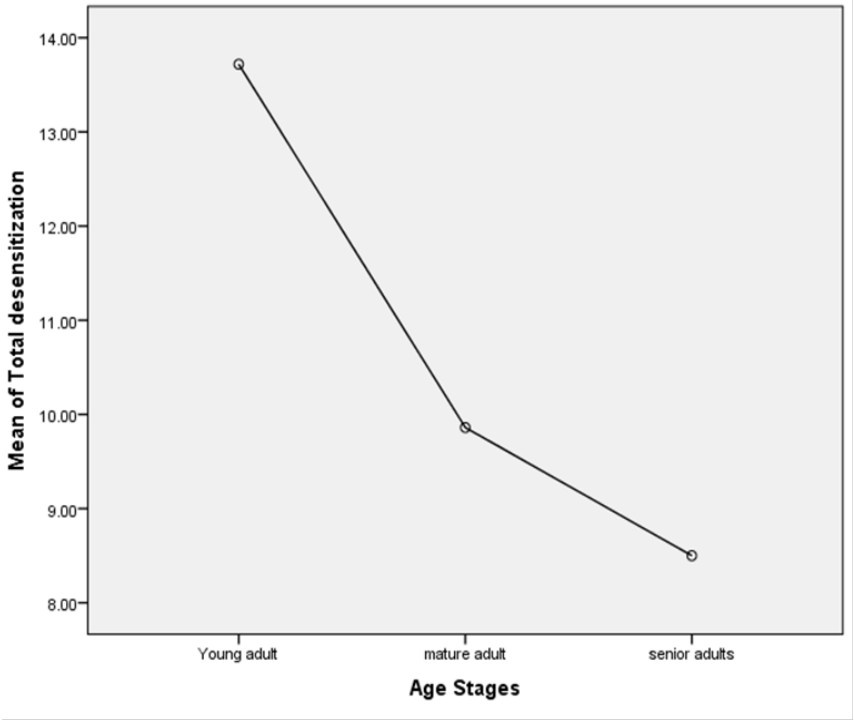

Figure I Means of desensitization to violence divided by age group.

The results suggest that the relationship between age and desensitization is close to the average and it is significant. The comparison sectioned by age (Table 2) shows significant difference between tha tree groups proposed, the ANOVA presents a significance of $\mathrm{p}<.001 \eta_{2=} .163$. The posthoc is shown as follow with Cohen's $d$, and effect size obtained by paired of age group.

The student's t test was used to presents the results of the comparison between people who reported having committed crimes and those who did not. The difference between the first group of 34 people with a mean of 14.91 SD 5.071 SE.87 and those who did not 11.21 SD 4.32 SE .225 can be clearly established. $t=4.71$ df $400 \mathrm{p}$ $<.001$ Cohen's d .845 and a effect size $=.365$.

Table 2 Post hoc of the comparison of desensitization to violence by age groups with Tukey HSD

\begin{tabular}{|c|c|c|c|c|c|c|c|c|}
\hline \multirow{3}{*}{$\begin{array}{l}\text { (I) Age stages } \\
\text { Young adults }\end{array}$} & \multirow{3}{*}{$\begin{array}{l}\text { (J) Age stages } \\
\text { Mature adults }\end{array}$} & \multirow{3}{*}{$\begin{array}{l}\begin{array}{l}\text { Mean } \\
\text { difference (I-J) }\end{array} \\
3.4677 \mid *\end{array}$} & \multirow{3}{*}{$\begin{array}{l}\text { Std. error } \\
0.55616\end{array}$} & \multicolumn{3}{|c|}{ Sig. 95\% Confidence interval } & \multirow{3}{*}{$\begin{array}{l}\text { Cohen's d } \\
0.9264\end{array}$} & \multirow{3}{*}{$\begin{array}{l}\text { Effect-size } r \\
0.4203\end{array}$} \\
\hline & & & & \multicolumn{2}{|c|}{ Lower bound } & \multirow{2}{*}{$\begin{array}{l}\text { Upper bound } \\
4.7761\end{array}$} & & \\
\hline & & & & .000 & 2.1593 & & & \\
\hline & Senior adults & $4.75938^{*}$ & 1.36924 & 0.002 & 1.5382 & 7.9805 & 1.431 & 0.58 \\
\hline Senior adults & Mature adults & 1.29167 & 1.43893 & 0.642 & -2.0934 & 4.6767 & -0.6526 & -0.310 \\
\hline
\end{tabular}

Finally, a comparison was made between the desensitization to violence mean in the city of San Luis Potosí and Tijuana's mean (places where the sample was taken). It was found that San Luis Potosí presents an average of 11.21 SD 4.212 and Tijuana 12.43 SD 5.17 a Cohen's d-.27 and an effect size-. 128 .

\section{Discussion}

This article aims to remark the situation that has existed in Mexico for generations now. As it can be appreciated, age has a negative and significant correlation; a matter that makes sense in a country like Mexico where violence has become a constant stimulus, therefore, the severity of violence is every time less perceived due to social labeling. ${ }^{9}$ This process takes relevance when the comparison with groups is carried out, if we think that media violence ${ }^{14}$ combined with social violence are crucial elements for desensitization to violence..$^{22}$ Therefore preventive intervention is an essential aim towards the new youth, providing elements that will allow them to resensitize and also understand that the perception of older people is not the same and therefore, the events that occur in everyday life are framed with a different magnitude, so, it is necessary to generate awareness to restore the social fabric and to reframe violent events.

In the same way as in the thesis of $\mathrm{F}$ Galán ${ }^{20}$ it is found that the desensitization to violence in adults is also associated with the possibility of having exercised a crime (or at least those who recognize it). In addition to this observation, it is important to return to what Akers \&Tarabah et al. ${ }^{5,16}$ point out, in a society in which crime or violence is constantly experienced, it is much more likely that it will be replicated and will continue happening. 
Finally, as was expected from the report of the Citizen Council for Public Safety and Criminal Justice, ${ }^{2}$ Tijuana appears with greater desensitization to violence presenting statistically significant differences (with a small effect size) compared to San Luis Potosí. The lower effect size may indicate that the process of desensitization does not exclusively affect the cities of the mentioned ranking, but other cities within the country, a subject that is of particular interest if we consider that Mexico has remained during the last years oscillating between the same places and quantity of cities in the ranking (not always with the same locations). This may be because violence as mentioned by Shukla \& Wiesner ${ }^{23}$ affects not only the people directly affected but also those around them.

In conclusion, it can be considered that the study of the desensitization to violence has made possible to realize that violence is not recognized in its small manifestations and that the forms in which the young population is alarmed are more extreme. The relationship between age and desensitization generates a clear picture of the social problem that exists in Mexico (and perhaps in the world), which affects both the intergenerational relationship and the possibility of taking actions for change, since the seriousness of the lived reality is not recognized.

Continuing with research regarding perceptions and beliefs (scripts, and social labeling) among different age groups, as well as proposing intervening actions to stop or reverse current violence, are still a pending agenda for researchers, legislators and civil society.

One of the limitations of the study is that the sample between San Luis Potosí and Tijuana is not proportional, and in the same way the sample of senior adults is very small. Additionally, only one variable was measured to make comparisons, therefore, it will be important to know if there are cultural, demographic, economic or belief mediators that generate a difference between one age group and another.

\section{Acknowledgements}

No funding to declare other than the Autonomous University of San Luis Potosí support to the payment of the publishing fees.

\section{Conflict of interest}

Authors declare that there are no conflicts of interest.

\section{References}

1. F Galán JS, Hernández NA, Martínez CM, et al. Desensitization to violence scale for adults. 2017.

2. https://www.seguridadjusticiaypaz.org.mx/ranking-de-ciudades-2017

3. http://www.inegi.org.mx/saladeprensa/boletines/2017/envipe/ envipe2017_09.pdf

4. http://visionofhumanity.org/app/uploads/2017/04/MPI17_English_ Report_WEB_03.04-1.pdf

5. Akers RL. Aplicaciones de los principios del aprendizaje social. Algunos programas de tratamiento y prevención de la delincuencia. 2009.

6. Bandura A. Aggression a social learning analysis. Prentice-Hall, New Jersey; 1973.

7. Bandura A. Social learning theory. Prentice-Hall, Estados Unidos de América; 1977.
8. Ghiso AM. Algunos límites de las respuestas frente a la violencia y la inseguridad, en las instituciones educativas. Revista Latinoamericana de Ciencias Sociales. 2012;10(2):815-824.

9. Huesmann LR, Guerra N. Children's normative beliefs about aggression and aggressive behavior. Journal of Personality and Social Psychology. 1977;72(2):408-419.

10. Cuevas MC, Castro L. Efectos emocionales y conductuales de la exposición a violencia en niños y adolescentes en Colombia. Psychology/ Psicología Conductual. 2009;17(2):277-297.

11. World Health Organization. Global status report on violence prevention 2014. World Health Organization: Luxemburg; 2014.

12. Salazar M. Un mal antiguo una larga historia. Noesis. 2011;19(38):109130 .

13. Cooley SM, Quille TJ, Griffin RS, et al. Effects of youth's exposure to community violence: the more project. Psychosocial Intervention. 2011;20(2):131-148.

14. Alimardani A, Ardekani AM, Astani LR. A Bio-Social Review to Mitigate the Punishment of Unwanted Acts. International journal of criminology and sociology. 2014;3:348-359.

15. Mrug S, Madan A, Cook EW, et al. Emotional and physiological desensitization to real-life and movie violence. Journal of youth adolescence. 2014;44(5):1092-1108.

16. Tarabah A. Kurdahi, L, Usta J, et al. Exposure to Violence and Children's Desensitization Attitudes in Lebanon. Journal of Interpersonal Violence. 2015;31(18):3017-3038.

17. Gaylord HNK, Dickson D, Pierre C. Profiles of Community Violence Exposure Among African American Youth: An Examination of Desensitization to Violence Using Latent Class Analysis. Journal of interpersonal violence. 2015;31(11):1-25.

18. Read GL, Ballard M, Emery LJ, et al. Examining desensitization using facial electromyography: violent videogames, gender, and affective responding. Computers in human behavior. 2016;62:201-211.

19. Funk JB, Baldacci HB, Pasold T, et al. Violence exposure in real life, video games, television, movies, and the Internet: Is there desensitization? Journal of Adolescence.2004;27(1):23-39.

20. F Galán JS. Contextos exposición y desensibilización a la violencia de adolescentes en instituciones. Doctoral Thesis, Universidad de Guadalajara. 2015

21. http://www.apa.org/ethics/code/index.aspx

22. Galán JS, Preciado. Violence desensitization: delimitating a construct through a theoretical revision. Uaricha. 2014;11(25):70-81.

23. Dushyant K, Wiesner M. Direct and Indirect Violence Exposure: Relations to Depression for Economically Disadvantaged Ethnic Minority Mid-Adolescents. Violence and Victims. 2015;30(1):120-135.

24. Krahé B, Möller I, Kirwil L, et al. Desensitization to Media Violence: Links With Habitual Media Violence Exposure, Aggressive Cognitions, and Aggressive Behavior. Journal of Personality and Social Psychology. 2011;100(4):630-64.

25. Su M, Mrug S, Windle M. Social cognitive and emotional mediators link violence exposure and parental nurturance to adolescent aggression. Journal of Clinical Child \& Adolescent Psychology. 2010;39(6):814 824. 